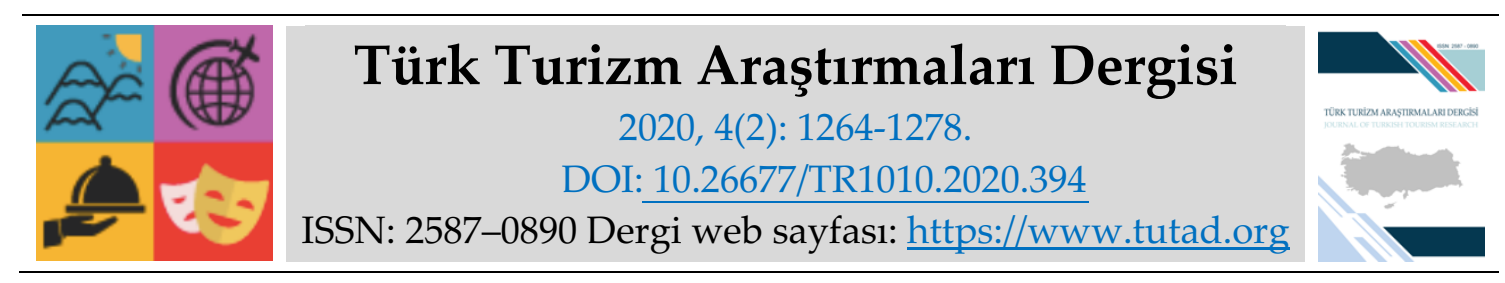

ARASTIRMA MAKALESI

\title{
Yiyecek-İçecek İşletmelerinde Yapay Zekâ Kullanımı
}

Öğr. Gör. Mehtap ÇERKEZ, İstanbul Esenyurt Üniversitesi, Sağlık Bilimleri Fakültesi, İstanbul, e-posta: mehtapcerkez@esenyurt.edu.tr ORCID: https://orcid.org/0000-0003-0494-8088

Dr. Öğr. Üyesi Özgür KIZILDEMiR, İstanbul Gelişim Üniversitesi, Uygulamalı Bilimler Yüksekokulu, İstanbul, e-posta: o.kizildemir@gmail.com

ORCID: https://orcid.org/0000-0003-4040-4547

Öz

Dünyada yapay zekâya olan talep yiyecek içecek sektöründe günden güne artmaktadır. Çalışma yapay zekâ ve robotik teknoloji uygulamasının yer aldığı bir restoranda gerçekleştirilmiştir. Araştırmada tüketicilerin teknoloji kullanımı ve beklentileri konusundaki mevcut durumunu ve yaş grupları arasındaki farkları ortaya çıkarmak amacıyla nitel araştırma yöntemi kullanılmıştır. Tüketici davranışlarını yerinde tespit etmek için katılımcı gözlem metodu kullanılmıştır. Araştırma sonunda tüm yaş gruplarının robotlara olan ilgisinin fazla olduğu tespit edilmiş ama akıllı masalara olan ilgi gençler arasında daha az iken, çocuklar tarafından daha çok kullanılmaktadır. Aynı zaman da akıllı masalar yemek sırasında fonksiyonel olarak kullanılamamaktadır. Tüketiciler yemek siparişi esnasında akıllı masayı kullanma yerine geleneksel sipariş yöntemini kullanmayı tercih etmektedirler. Araştırma sonucunda edinilen bulgular doğrultusunda, ülkemizde yeni olan bu uygulamalar, Dünya'daki benzer gelişmeler takip edilerek geliştirilmelidir. Böylelikle tüketici beklentileri karşılanacak, sektörün gelişmesi sağlanacaktır.

Anahtar Kelimeler: Yapay Zekâ, Robot, Akıllı Masa, Tüketici, Restoran.

Makale Gönderme Tarihi: 23.12.2019

Makale Kabul Tarihi: 06.04.2020

\section{Önerilen Atıf:}

Çerkez, M. ve Kızıldemir, Ö. (2020). Yiyecek-İçecek İşletmelerinde Yapay Zekâ Kullanımı, Türk Turizm Araştırmaları Dergisi, 4(2): 1264-1278.

(C) 2020 Türk Turizm Araştırmaları Dergisi. 


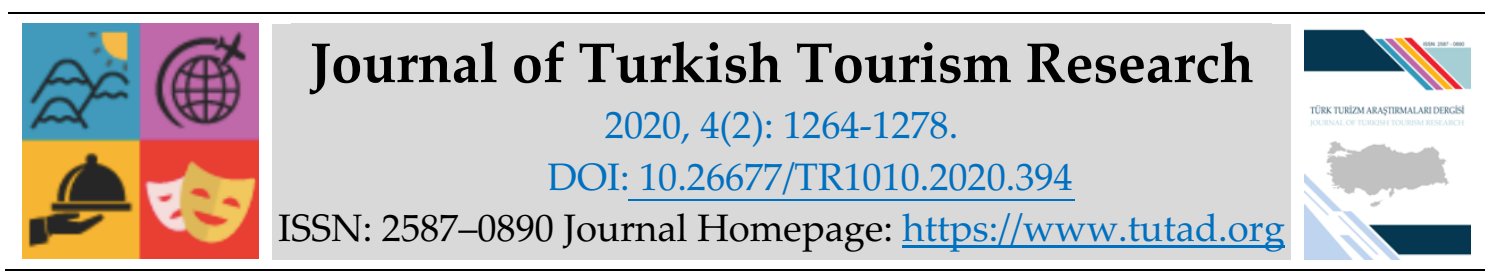

\title{
RESEARCH PAPER
}

\section{Use of Artificial Intelligence in Food and Beverage Business}

Lecturer Mehtap ÇERKEZ, İstanbul Esenyurt University, Faculty of Health Sciences, İstanbul, email: mehtapcerkez@esenyurt.edu.tr ORCID: https://orcid.org/0000-0003-0494-8088

Assistant Prof. Dr. Özgür KIZILDEMIR, İstanbul Gelişim University, School of Applied Sciences, İstanbul, e-mail: o.kizildemir@gmail.com ORCID: https://orcid.org/0000-0003-4040-4547

\begin{abstract}
The demand for artificial intelligence in the world is increasing day by day in the food and beverage industry. The study was carried out in a restaurant with artificial intelligence and robotic technology application. In the research, qualitative research method was used to reveal the current status of consumers on technology usage and expectations and the differences between age groups. Participatory observation method was used to detect consumer behaviors on-site. At the end of the research, it has been determined that all age groups have a great interest in robots, but the interest in smart tables is less among young people, but it is used more by children. At the same time, smart tables cannot be used functionally during meals. Consumers prefer to use the traditional order method instead of using the smart table when ordering food. In line with the findings obtained as a result of the research, these new applications in our country should be developed by following similar developments in the world. Thus, consumer expectations will be met and the sector will be improved.
\end{abstract}

Keywords: Artificial Intelligence, Robot, Smart Table, Consumer, Restaurant.

Received: 23.12.2019

Accepted: 06.04.2020

\section{Suggested Citation:}

Çerkez, M. and Kızıldemir, Ö. (2020). Use of Artificial Intelligence in Food and Beverage Business, Journal of Turkish Tourism Research, 4(2): 1264-1278.

(c) 2020 Türk Turizm Araştırmaları Dergisi. 


\section{Gíriş}

Teknolojik gelişmeler "Dijital Çağ" olarak isimlendirilen yeni bir dönemi başlatmıştır. Bu dönemde sanayi ile beraber tüm sektörleri etkileyen hızlı ve köklü bir değişim söz konusudur. Dijital çağ, sınırlı bilgi ortamından genişletilmiş bilgi dünyasına geçişi, sektörlerin bilgi toplama sürecini ve iletişimini, kuşakların da hayatlarını ve yaşam tarzlarını değiştirmektedir. Z kuşağının (2000 yılından itibaren dünyaya gelmiş bireylerin oluşturduğu nesil) doğduğu yıllardan itibaren teknolojik gelişmelere bakıldığında, çarpıcı dijital gelişimlerin ve teknolojik icatların kullanılmaya başlandığını görülmektedir. Örneğin; 2000 yılında USB flash sürücülerin kullanıma başlanmış, 2013 yılında ilk insansı robot denemeleri yapılmış, 2015 yılında ise 3D yazıcı temelli üretim ve 4.5G başlamıştır (Kayıkçı ve Bozkurt, 2018:55). Teknolojinin gelişmesi ile insanın düşünme, nesnel gerçekleri algılama, algılama, akıl yürütme, muhakeme etme ve sonuç çıkarma kabiliyetlerinin bütünü olarak nitelendirilen zekânın makineler üzerinde görülme isteği, bilim insanlarını yapay zekâ geliştirmek için araştırmalar yapmaya yöneltmiştir.

Yapay zekâ, bir bilgisayar modelinin insan zekâsına özgü nitelikleri olan görsel algılama, ses tanıma, fikir üretme, düşünme, öğrenme, problem çözme, geçmiş deneyimleri saklama, karar verme gibi bilişsel fonksiyonları ve otonom hareketleri göstermesi olarak tanımlanmaktadır (Yıldız ve Yıldırım, 2018). Yapay zekânın tarihi 1950 yıllarına dayandırılsa da aslında çok eski tarihlerde de insanların otomatik makineler yapma isteği ve denemelerinin olduğu bilinmektedir. Örneğin; M.S. 1. Asırda İskenderiyeli Heron hava basıncıyla çalışan otomatik açlıp kapanan kapı, buhar türbini vb. yapmıştır (Topdemir, 2011:90). 13. asırda Artuklu sarayında yaşamış olan Ebul İz El Cezeri, otomatik kuşlar, otomatik yüzen kayık, otomatik abdest alma ve su akıtma, su dolabı, şifreli anahtarlar ve robotlar gibi su ve mekanik parçalarla çalışan makineler yapmıştır (Ertürk ve Yayan, 2012:454). Bu alanda ilk ciddi adım 1956 senesinde ABD'de de düzenlenmiş olan Darthmouth Konferansı'nda atılmıştır ve John McCarthy (19272011) günümüz yapay zekâ teknolojisinin gerçek öncüsü kabul edilmektedir (Kayıkçı ve Bozkurt, 2018:57). Türkiye'de ise yapay zekâ ile ilgili çalışmalara bakıldığında; Hakan Altınay tarafından 1990 yılında Türkiye'nin ilk beş eksenli robotu İstanbul Teknik Üniversitesi'nde yapılmış, 1994 yılında ise Türkiye'nin ilk teknoloji geliştirme merkezinde ilk sınai robot imal edilmiştir (Yülek, 2018).

21. yüzyılın ilk çeyreğine geldiğimiz bu günlerde artan yiyecek ve içecek talebini karşılamak, endüstride olan karmaşayı kolay bir biçimde çözümlemek için makine öğrenme modelleri geliştirilmektedir. Gıda üretimi ve yiyecek içecek sektöründe hizmet veren iş kollarında yapay zekâ uygulamaları endüstriyi farklı bir düzeye taşımaktadır. Daha az insan hatası, daha az israf, üründen maksimum fayda sağlama, hızlı hizmet, güvenilir şeffaf gıda, müşteri memnuniyeti, kişiselleştirilmiş özel siparişler gibi faydaları sayılabilmektedir. Gün geçtikçe daha fazla firma müşteri memnuniyeti sağlama ve gelirini arttırma odaklı olarak, yapay zekâ özellikli teknolojik ürünleri kullanmaya başlamış ve önümüzdeki yıllar içinde gıda sektöründe yapay zekâ özellikli teknoloji kullanımın çok daha fazla artacağı ön görülmektedir. Yiyecek ve içecek piyasasında yapay zekâ - büyüme trendler ve tahmin (2019-2024) raporuna göre; yapay zekânın yiyecek içecek piyasasında 2019-2024 yılları arasındaki tahmin döneminde \%65,3 ‘ün üzerinde bir yıllık büyüme hızı kaydetmesi beklenmektedir (www.mordorintelligence.com).

Yiyecek- içecek sektörü için geliştirilen yapay zekâ ve robotik teknoloji uygulamalarının tüketici tarafından kullanılması durumu merak konusudur. Bu noktadan hareketle yapay zekâ ve robotik teknoloji uygulamasının yer aldığı bir restoranda, tüketicilerin teknoloji kullanımı ve beklentileri konusunda mevcut durumunu ortaya koymak, farklı yaş grupları arasındaki ayrımları ortaya çıkarmak araştırmanın amacını oluşturmaktadır. 


\section{YIYYECEK-İÇECEK SEKTÖRÜNDE KULLANILAN YAPAY ZEKÂ UYGULAMALARI}

Bilgi toplama, problemlerin çözümü ve analizlerinin yapılması gibi birçok konuda yapay zekâya başvurulmaktadır. Keşfedilen bu yapay zekâ uygulamaları sayesinde bu alanında getirilen pek çok yenilik, yiyecek- içecek kalitesini arttırma, yiyecek ve içeceğin güvenliğini sağlama, ürünü standartlaştırma gibi yararlar sağlamaktadır. Bu yapay zekâ uygulamaları; yapay sinir ağları (neural network), bulanık mantık (fuzzy logic) ve genetik algoritmadır (genetic algorithm).

Yapay sinir ağları; beynin bir işlevini yerine getirme yöntemini modellemek için tasarlanmış bir sistemidir. Donanım olarak bilgisayarda yazılım ya da elektronik devrelerle oluşturulabilir. Yapay sinir ağları bilgiyi saklama ve genelleme yeteneğine sahip paralel dağılmış işlemci yapısına sahiptir. Yiyecek ve içeceklerde proses modelleme, optimizasyon kalite kontrolünün izlenmesi ve sınıflandırmayı sağlar. Örneğin; büyük mısır tanelerinin kırılmış olanlardan ayrılması, antosiyonin içeriklerinin belirlenerek şarapların kategorize edilmesi, mikrobiyal çalışmalarda mikrobiyel gelişimin belirlenmesi, biyoreaktör problar ve elektronik burun (electronic nose-EN) ölçümlerden elde edilen verilerle yapay sinir ağları ile laktat, galaktoz, ve laktoz içeriklerine göre proses modellemesi gibi anlarda kullanılmaktadır (Sofu vd., 2007:94).

Elektronik burun; insan koku alma mekanizmasını taklit ederek çalışan sistem olarak isimlendirilmektedir (Kızıl vd., 2011:111). Elektronik burun kalite kontrol, proses hazırlama, tazelik değerlendirilmesi, raf ömrü değerlendirmesi ve orijinallik gibi birçok değerlendirmelerde kullanılmaktadır. Et, tahıl, kahve, mantar, peynir, deniz ürünleri, alkollü içecekler ve alkolsüz içecekler, zeytinyağı gibi birçok gıda ürünü ile ilgili elektronik burun araştırmaları yapılmıştır (Korel ve Balaban, 2003:508). Örneğin; 10 farklı metal oksit sensörlü özel bir elektronik burun cihazı kullanarak farklı olgunluk durumlarında olan domatesler (olgunlaşmamış, yarı olgun, tam olgun ve aşırı olgun) arasında ayrım yapıp yapılamayacağı araştııılmıştır. Kullanılan elektronik burun cihazı farklı domates olgunluk durumlarını ayırt ederek domateslerin tamamını sinıflandırmıştır (Gomez vd., 2006:51).

İnsanlar gündelik yaşamda problemlerini çözerken tam olarak tanımlanmamış olan soğuk, çok sıcak, ılık, hafif soğuk gibi sayısal olmayan ifadeler kullanarak çözerler. Bulanık mantık yönteminde de kesin değerlere dayandırılan düşünme yerine yaklaşık düşünme kullanılmaktadır. Yapay zekâ uygulamalarından biri olan bulanık mantık gıdalarda kümeleme, sınıflandırma, ürün derecelendirme, ürün tasarımı gibi alanlarda kullanılmaktadır. Örneğin; gıdalarda kızartma süresinin tahmini, elmaların sertlik derecelerine göre sınıflandırılması, domateslerin kalite kriterlerine göre sınıflandırılması gibi durumlarda bulanık mantık yöntemi kullanılmaktadır.

Genetik algoritma; doğal seçim ve doğal genetik mekanizmasına dayalı bir algoritmadır. Kullanıcı ayrıntılı olarak matematik ve algoritma bilgisine sahip olmadan kolayca problemi kodlayabilmektedir. Genetik algoritma kendi kendine öğrenme ve karar verme sistemlerinin düzenlenmesini amaçlamaktadır. Ürün tasarımı depolama sistemlerinin kontrolü, ürün rekoltesinin tahmini gibi kullanım alanları sağlamaktadır. Raf ömrü kısa olan gıda ürünlerinde satış süresinin yapay sinir ağları ve genetik algoritma ile belirlenmesi sağlanmaktadır (Sofu vd., 2007:96). Vişne suyunun antioksidan aktivite uygun değerleri belirlemesi ile ilgili yapılan araştırmalarda genetik algoritma kullanımın etkin bir yöntem olduğu saptanmıştır (Türken ve Pala, 2016:246). 


\section{YIYYECEK İÇECEK SEKTÖRÜNDE YAPAY ZEKÂNIN KULLANIM AMAÇLARI}

Yapay zekâ, temel olarak iş süreçlerini kolaylaştırmaya, çalışanların işlerini kolaylaştırmaya ve işlemleri daha verimli hale getirmeye yardımcı olmaktadır. Yiyecek içecek sektörü de bu son teknolojik gelişmelerden büyük ölçüde faydalanmaktadır (Utermohlen, 2019). Yiyecek içecek sektöründeki tüm teknolojilik gelişmeleri kapsayan teknoloji; robotik, veri teknolojisi, yeni işleme teknikleri ve yeni uygulama alanları yaratmaktadır. Tarım alanında, dronlar ve robotlar ile çiftçilere kolaylık sağlama, iklime dayanıklı ürün çeşitliliği, balık yetiştiriciliğin geliştirilmesi, yeni protein kaynaklarının üretimi, biyoteknoloji ile gida güvenliği sağlama gibi uygulamalarla yüksek verim düşük çevresel etki amacıyla kullanılmaktadır. Yiyecek içecek sektörü açısından bakıldığında ise amaç yüksek kaliteli ürün ve düşük maliyettir. Bu amaç doğrultusunda kısa vadede robotlar, veri işleme teknolojisi ve yeni işleme teknikleri, uzun vadede ise, yiyecek içeceklerde nano ölçekli içerikler, yiyecek üretiminin kişiselleştirilmesi ile 3D baskı, hücre teknolojisi umut vermektedir (Geijer, 2019).

Yapay zekânın yiyecek içecek sektöründe dolaylı etkisini beş başlık halinde toplamak mümkündür. Bunlar; yiyecek ve içeceklerin sıralanmasına yardımcı olmak, tedarik zincirini yönetmek, çalışanların kişisel hijyen prosedürlerini takip etmelerini sağlamak, yeni ürünler geliştirmek, temizlik işlemi donanımlarını yönetmektir (Garver, 2018).

\section{Yiyecek ve İçeceklerin Sıralanması}

Yiyecek içecek sektöründe şirketlerinin karşılaştı̆̆1 ilk operasyonel zorluk hammaddeleri sınıflandırmaktır. Her ürünün kalitesi farklıdır bu nedenle sıkı bir tasnif gereklidir. Yapay zekâ gibi yeni teknolojilerle otomatikleştirilmezse bu tasnif işlemi çok zaman almakta ve çok büyük miktarda insan emeği gerektirmektedir (Sharma, 2019).

1970'li yıllarda kurulan ve şu anda sektörde öncü firma olarak yer alan TOMRA yiyeceklerin sıralanması konusunda farklı sensör teknolojileri kullanmaktadır. Benzer yapı veya renk özelliklerinden dolay tanımlanması güç olan kusurların ve yabancı maddelerin tespiti için "Gelişmiş Yabancı Madde Detektörü (AFMD)" iyi ürün ve kusurların özelliklerini tanımlayan, denetlenen nesnelerdeki belirli kimyasal ve moleküler farklılıkları belirleyen "Biyometrik İmza Tanımlaması (BSI)", renk, uzunluk, genişlik, çap, alan vb. özellikleri tanıan "Camera", alfatoksin tespitini sağlayan "Detoks", klorofil /solanin içeriğine göre besinleri ayıran "Fluo ", etin içine nüfus ederek yağın doğru ölçümünü sağlayan "Etkileşim Spektroskopisi", renk, yapı ve biyolojik özelliklere göre sınıflandıran "Lazer", ürünlerin su içeriğine göre sıralamasını sağlayan "Kısa Dalga Kızılötesi (SWIR)" gibi pek çok teknolojik yöntemi, gıda ayırma teknolojisi olarak yiyecek içecek endüstrisine sunmaktadır (Food Sorting Tecnology By Tomra, 2019).

\section{Tedarik Zincirini Yönetmek}

Tüketiciler, yiyecek ve içeceklerin nereden geldiği ve tüketicilerin taleplerinin karşılanması konusunda üreticilerin daha fazla bilinçli olmasını istemektedir (Murkett, 2017). Şirketlerin tedarik zincirinin her aşamasında gıda güvenliğini test etmeleri ve izlemeleri, fiyatlandırma ve envanteri yönetmeye yardımcı olurken aynı zamanda çiftlikten tüketiciye şeffaflığı sağlamaktadır (Utermohlen, 2019). Bu alanda kullanılan yapay zekâ, perakendecilerin talebi doğru bir şekilde tahmin etmesine, ürünleri raftan daha hızlı hareket ettirmesine, bozulmadan ve taze yiyecek israfından kaçınmasına yardımcı oluyor. Symphony Retail firması, talep tahmini, mutfak yönetimi, raf alanı planlama, depo yönetimi gibi perakende çözümlerle yapay zekâyı etkili bir şekilde kullanıp gıda endüstrisine sunmaktadır (www.marketwatch.com). Günümüzde artık 
yiyecek içecek sektörü içerisinde yer alan pek çok şirket kalite güvencesini geliştirmek, daha iyi tahmin modelleri sağlamak ve tüketici eğilimlerine ayak uydurmak için yapay zekâ kullanmaktadır (Murkett, 2017).

\section{Çalışanların Kişisel Hijyen Prosedürlerini Takip Etmelerini Sağlamak}

Yiyecek içecek fabrikalarında ve mutfakta, gıdaların güvenilir olmasını sağlamak için kişisel hijyen önem arz etmektedir. KanKan gibi firmalar sağllğa uygunluk durumunu arttırmak için yapay zekâ ile çalışan çözümler üretmeye çalışmaktadır. Mutfaklarda ve restoran içlerinde kullanabilen kamera sistemi, çalışanları izlemek, gıda güvenliği gereği şapka maske el hijyeni gibi kuraların uygulanıp uygulanmadı̆̆ını gözlemlemek yüz tanıma ve nesne tanıma yazılımları kullanıp ihlal söz konusu olduğunda ilgili kişiye görüntülerin aktarımını sağlamaktadır (Utermohlen, 2019).

\section{Yeni Ürünler Geliştirmek}

Yiyecek içecek sektörü, tek bir şirketin sağlayabileceği çok fazla ürün olduğu için benzersizdir. Tüketicilerin isteklerini bulmak zor olduğundan şirketler bu zorluğu yapay zekâ kullanımı ile aşmaya çalışmaktadırlar (Garver, 2018). Gastrograph AI insanın duyusal algısını modellemek ve yiyecek içecek ürünlerinin tüketici tercihlerini kontrol etmek için kullanılan bir yapay zekâ platformudur. Yeni ürün geliştirme, portföy yönetimi, ürün uyarlaması, derin piyasa görüşleri gibi hizmetlerle tüketicilerin lezzet ve tercih algılarını anlayan bir yapay zeka geliştirerek üreticiye sunmaktadır (www.gastrograph.com). İçecek devi olarak bilinen Coca- Cola firması 500 'den fazla marka satın alarak müşterilerine 3500'den fazla içecek türü teklif etmiştir. Yapay zekâ kullanılmadan önce marka müşterilerinin ne istediğini belirlemek için anketler ve kampanyalar yapılmaktaydı. Ancak günümüzde teknolojinin gelişmesi ile hangi yeni ürünlerin yaratılması gerektiği konusunda bilgilenmek için bu tür yollara başvurulmamaktadır. Coca- cola bireylerin kendi içkilerini kişiselleştirmelerini sağlayan self servis meşrubat bölümü oluşturmuş ve müşterilerin bu self servis makinelerini kullanarak temel içeceklerini farklı tatlar ekleyerek oluşturmalarını sağlamıştır. Self servis içecek bölümünden yapay zekâ sayesinde verileri toplayan firma bu veriler sonucunda Cherry Sprite ürünü piyasa sürmüştür.

\section{Temizlik İşlemi Donanımlarını Yönetmek}

Nottingham Üniversitesi'ndeki araştırmacılar tarafından temizleme süresini ve kaynaklarını azaltmak için yapay zekâ sistemi geliştirmiştir. Yiyecek ve içecek üretim donanımlarını daha net bir şekilde temizlemek için geliştirilen akıllı sensor sisteminin İngiltere endüstrisi için yılda 100 milyon sterlin tasarruf sağlayabileceği ifade edilmiştir (www.nottingham.ac.uk). Notingham Üniversitesi'nin verilerine göre donanım temizliği, bir gıda işleme tesisinin enerji ve su kaynaklarının \%30 'unu oluşturmaktadır. Yapay zekâ teknolojisi uygulamalarıyla yılda yaklaşık 133 milyon dolar tasarruf sağlanabildiği ve aynı zamanda donanımları temizlemek için zaman (\%50), enerji ve su tasarrufu sağlandığı ifade edilmiştir (Sharma, 2019).

\section{YİYECEK İÇECEK SEKTÖRÜNDE MODERN TEKNOLOJİ UYGULAMALARI}

Teknolojik yenilikler, tüketiciye daha üst düzey bir hizmet sunmak isteyen sektörler için bir değişim ve gelişim kaynağıdır. Restoran sahipleri için önceleri yemek siparişi vermek için kullanılan teknoloji günümüzde farklı bir boyuta ulaşmıştır. İnteraktif akıllı masalar, sanal 
çubuklar ve robotlar sayesinde gelişmiş bir teknik hizmet ve müşterilerin farklı bir deneyim yaşamasını sağlayan yenilikler yiyecek ve içecek sektörü için heyecan vermektedir.

Dışarıda yemek yeme olgusu artık günümüzde sosyalleşme, iletişim ve eğlence aracı kullanılmaktadır. Bu amaçla, yemek yoluyla insan iletişimini ve sosyalleşmeyi, eğlendirmeyi ve geliştirmeyi amaçlayan girişimler, ticari çözümler olarak ortaya çıkmaktadır. Bu yeniliklerden biri olan akıllı masalar, yemek ve eğlence için yeni bir yol olarak tanımlanmaktadır (Margetis vd., 2013:666).

Akıllı masa ürünlerini geliştiren "intercative restaurant technology" firması farklı kullanım özelliklerine ait akıllı masaları satışa sunmaktadır. Halka açık alışveriş merkezleri gibi mekânlarda kullanım için dijital sipariş, bilgi alışverişi ve kafeler için ödeme seçeneği sunan cafe masaları, yapay zekâ destekli garsonsuz sipariş, sosyal medya kullanımı, oyun, parmak boyama, diğer masalardaki kişilere mesaj gönderme gibi özellikleri bulunan kapsamlı apps koleksiyonu masaları gibi farklı temalarda akıllı masaları sunmaktadır (www.itrestaurant.net). Örneğin Londra da bulunan "inamo" restoranı misafirlerine farklı deneyim yaşatmak için akıllı masaları kullanmaktadır. Kullandığı teknoloji ile ünlü olmaya çalışan restoran 2019 yılında "Teknolojinin En İyi Kullanımı" ödülünü almıştır. Kullandığı akıllı masalar ile müşteriye canlı şef kamerası ile mutfak operasyonunu görüntüleme, oyun oynama, masaüstünü süsleme gibi birçok olanak sağlamaktadır (www.inamorestaurants.london).

Nimesha Ranasinghe ve Singapur Ulusal Üniversitesi'ndeki ekip tarafından "voctail" sistemi geliştirilmiştir. Vocktail sisteminde, sanal tatlar yaratmak ve içeceğin mevcut tatlarını arttırmak için üç ortak duyu kullanılmaktadır. Bu duyular; tat, koku ve görselliktir. Vocktail gerçek bir kokteyl tadı, kokusu ve görünümünü simüle etmektedir. Oluşturulan üründe, cama pompalanan bir koku, çeşitli renk yayan bir LED ışık ve camın kenarında bulunan iki gümüş elektrot kullanılmaktadır. Elektrotlar, tercihinize ve vocktail seçiminize bağlı olarak tuzlu veya ekşi hisleri uyarmak için dil üzerindeki elektrik akımlarını kullanmaktadır. Oluşan sinyaller sonucu beyinde istenilen tadı hissi oluşmaktadır. Örneğin köpüklü su içildiğinde, beyin bu içeceği bir gazoz olarak algilayabilmektedir. Oluşturulan bu teknolojinin; özel tatlar yaratma, sosyal medya aracıllı̆̆1 ile arkadaşlarınla paylaşma, özel diyet tedavisi uygulanan bireylerde diyette kısıtlanan ürünleri sanal olarak tatmayı sağlaması gibi pek çok faydası vardır (Fourtané, 2018).

Uluslararası Robotik Federasyonu verilerine göre yıl içinde yiyecek içecek endüstrisinde satılan robotların satışları artış göstermektedir. Avrupa ülkelerinde 2013 yılında 3,192 adet, 2016 yılında 3,412 adet 2017 yılında ise 3,766 adet satılmıştır. Dünya genelindeki satış oranlarına bakıldığında ise, 2013 yılında 6,200 adet, 2016 yılında 8,194, 2017 yılında ise 9,724 robot satışı yapılmıştır. İsveç ve Danimarka ülkeleri en yüksek robot yoğunluğuna sahip ülkelerdir. Bu ülkeleri Hollanda ve İtalya takip etmektedir (Geijer, 2019). Restoranlar, yiyecek hazırlama ve sunma kapasitesini ve hızını artırmak için yapay zekâ güdümlü robotlar kullanmaktadır. Restoranlarda, yapay zekâ robotları müşterilerin siparişlerini alabilir, yemeği hazırlayabilir ve hazırlanan yemeği müşterilere sunabilirler. Bu robotların kullanımı ile birlikte iş yükü azalmakta ve yiyecek hazırlama süreci maliyet ve zaman açısından işlemi standartlaştırmaktadır. Boston'da yer alan Spyce restoranı robotik mutfağa sahip ilk restoranlardan biridir. Vejeteryan, glütensiz, vegan gibi birçok seçeneklerle yemekleri kişiselleştiren restoranda garson bulunmamaktadır. Yemekleri tercihine göre dokunmatik ekrandan seçen müşterinin yemeği robotlar tarafından hazırlanıyor ve şeflerin son dokunuşu ile yemeğe hazır halde sunuluyor (www.spyce.com).

Yemek servisi ve mutfaklarda kullanılan robot örneklerine bakıldı̆̆ında; Moley (dünyanın ilk ev robotik şefi) Londra merkezli Moley Robotics şirketi tarafından "Robo-Şef" ilk defa 2015 yılında üretmiştir. Set üstü ocak, mutfak robotu, bulaşık makinesi, temel aletler ve mutfak eşyaları bulunan bir mutfaktır. Yemek hazırlayan insanın hareketlerini kaydedip ne yapması 
gerektiğini öğrenen robot iki gelişmiş kolu sayesinde yüzden fazla farklı yemek pişirebilme özelliğine sahiptir (Walker, 2018). Flippy kızartma 1zgara, hazırlama ve kaplama işlemlerine yardımcı olan başka bir yapay zekâ ürünüdür. Sıcaklık kontrolü ve gıdayı izlemesine görmesine izin veren sensörler ve kameralarla bütünleşmiş yazılım ile çalışmaktadır. Fast food sektörü çalışanlarının devir hızı yüksek olduğu bir sektördür. Bu sektörde yer alan CaliBurger firması 2017 yılında California 'da Flippy robotlarını kullanmaya başlamıştır. Japon teknoloji şirketi SoftBank, "Pepper" adında bir insansı robot üretmek için MasterCard ile işbirliği yapmıştır. Pepper, müşteri siparişlerini işleyen, ürün önerileri sunan ve müşterilerin robotun el tabletini kullanarak hesaplarıyla ödeme yapmalarını sağlayan bir robot garsonudur (Sennaar, 2019).

Chatbots, restoranların müşteri taleplerine cevap vermek, müşteri siparişlerini işlemek ve kişiye özgü siparişler oluşturmak için yapay zekâ üzerine kurulu sanal asistanlardır. Örnek uygulamalara bakacak olursak bu yapay zekâ uygulamalarından biri olan" Say2eat" 2015 yılında ortaya çıkan bir girişimdir. Say2eat gida hizmet zincirleri ve perakendecilere, müşteri ilişkileri becerilerini geliştirmelerinde yardımcı olmaktadır. Facebook mesenger, SMs ve Amazon Echo gibi uygulamalara bütünleştirilen Say2eat sayesinde tüketiciler kolaylıkla sohbet botları ile restorana yemek siparişi verebilmektedir (Walker,2018). Pizza satışı ile tanınan "Dominos" firması 2017 yılında Facebook messenger üzerinden sohbet botu geliştirmiş ve tüketicinin "pizza" kelimesini içeren mesaj gönderimi sonucu sipariş vermesini sağlamıştır (Sennaar, 2019). Daha sonrasında Dominos yapay zekâ kullanımını pizza servisine taşımış, pizzanın kalitesini kontrol eden “Dom Pizza Checker" ile dünyanın ilk akıllı tarayıcısını kullanmaya başladığını açıklamıştır. Şu anda sadece Yeni Zelenda ve Avustralya mağazalarında kullanılan bu sistem, pizza tipine doğru malzeme kullanımına hatta peynirin eşit dağılımına kadar analiz edebilmektedir. Ayrıca yapılan her pizzayı fotoğraflayıp tüketicinin pizzasının kontrolünü de sağlamaktadır (Diaz, 2019).

Tavsiye motorları; tüketicilerin yemek tercihlerine göre yemek seçmelerine yardımcı olmak için tasarlanan yapay zekâ uygulamalarıdır. İnsanların zevkini belirleyen böylece insanların doğru seçimler yapmalarını sağlayan yapay zekâ uygulamalarından biri olan "Halla" 2016 yılında Los Angeles merkezli olarak kurulmuştur. Tavsiye motorunun kullanılmasıyla müşteriler önceden belirlenmiş olan lezzet profili ve özelliklerine uygun yemek deneyimleriyle eşleştirilmektedir. Müşterin yemek tercihleri ve konumlarına uygun olacak şekilde, müşterinin ilgisini çekebilecek restoranlarla ilişkilendirmeyi sağlamaktadır. 2013 yılında yapay zekâ uygulamaları üzerine kurulan "TellSpec" şirketi ise insanlara seçtikleri yemekler konusunda daha sağlıklı seçimler yapma özelliğini sunmaktadır. TellSpec tarafından geliştirilen cihazın bir gıdaya doğru yönetilmesi sonucunda, gıda hakkindeki yağ değeri, toplam kalori değeri, glisemik indeks değeri gibi verileri cep telefonu uygulamasına yansitmaktadır.

Kiosks; restoranlar müşterilerin bekleme süresini azaltmak ve müşteri sipariş deneyimini geliştirmek için oluşturulmuş yapay zekâ uygulamalarıdır. McDonald's, Wendy, KFC Kiosk'u uygulayan örnek firmalar arasında yer almaktadır. McDonald'sın self servis Kiosksu dijital menü kartları kullanarak hava durumuna göre, mevsimlere göre ve müşterinin tercihlerine göre önerilerde bulunmaktadır. İçeceklerin şeker miktarı, hamburgerlerin sos seçimleri ve tuz seçimi gibi kişiselleştirmeler sunan dokunmatik ekrana sahiptir. Bu ekran üzerinden yemek seçimini yapan müşteri siparişini tamamlayıp ödemesini de gerçekleştirebilmektedir. Kiosk kullanan bir diğer firma KFC ise müşterilerin yüzleri, yaşları, cinsiyet ve ruh hali gibi tercihleri etkileyebilecek kişisel özelliklerini kullandığı teknoloji ile yüz taraması yaparak müşteriye uygun menüyü sunmayı amaçlamıştır. Tanınan yüzler kayıt altına alındığından müşterinin tekrar eden ziyaretlerinde önceki seçimlerinden yola çkarak önerilerde bulunmaktadır (Sennaar, 2019).

Yiyecek içecek sektöründe yapay zekâ teknolojisinin kullanım amaçları doğrultusunda ortaya çıan kioks, tavsiye robotları, chatbots, robotlar, akıllı masa gibi teknolojik uygulamalar sektöre pek çok 
fayda sağlamaktadır. Personel alımı ve yönetmekle ilgili masrafları ve stresi azaltarak tasarruf, verimlilik, insan hatasını ortadan kaldırdığı için daha az hata, tekrarlanan işlerin daha hızlı yapılabilmesi gibi pek çok fayda sıralanabilir. Bu teknolojik yeniliklerin getirdiği faydaların yanı sıra risklere bakıldığında ise, yapay zekâ türünün geliştirilmesi ve uygulanması maliyetlidir ve bu nedenle daha çok sektörde belirli büyüklüğe sahip işletmeler tarafından tercih edilmektedir. Bir başka risk ise işletme sahiplerinin değişikliklere ayak uydurmak için, durgunluğa engel olmak için kullandıkları teknolojik uygulamaları yükseltmek zorunda kalmaları ve ödeme yapmaya devam etmeleridir. Ayrıca sektörde insanların yerine yapay zekâ uygulamalarının yer alması işsizlik sorununu gündeme getirebilir. Sektörde kullanılan yapay zekâ uygulamaları ve teknolojinin getirdiği faydaların, risklerden daha ağır bastığına inanılmaktadır ve bu inanışla birlikte yapay zekâ uygulamaları, yiyecek içecek sektöründe hızlı bir ivme ile gelişmeye, büyümeye devam etmektedir (Eriksen, 2019).

\section{YÖNTEM}

Yapay zekâ ve robotik teknoloji uygulamasının yer aldığı bir restoranda, tüketicilerin teknoloji kullanımı ve beklentileri konusunda mevcut durumunu ortaya koymak ve yaş grupları arasındaki farkları ortaya çıkarmak amacıyla nitel araştırma yöntemi kullanılmıştır. Araştırmada tüketici davranışlarının daha açık bir şekilde tespit edilebileceği düşünülerek, nitel araştırma yöntemlerinden biri olan gözlem tekniklerinden, katılımcı gözlem metodu kullanılmıştır. Gözlem; kişilerin belirli konulardaki davranışlarının, araştırmacının gözünden yerinde gözlemlenmesidir. Gündelik yaşam akışı içinde belirlenen ortamdaki kişilerin gözlenmesine dayalı olan doğal ortam gözleminde kişiyi hedefe yönelten unsurların gözlemlenmesi daha kolaydır (Kozak, 2018 :85). Gözleme dayalı araştırmalarda elde edilen bulguların sayısallaştırması güç olduğundan veriler gözlemcinin saptamaları doğrultusunda ortaya çıkmıştır (Yıldırım ve Şimsek, 2016:177).

Türkiye' de yapay zekâ ve robotik uygulamaların restoran içinde kullanımının çok yeni olması ve örneklem büyüklüğünün oldukça küçük olması bu çalışmanın sınırlılıklarındandır. Araştırmaya katılacak restoran, nitel araştırma desenlerinden örnek olay araştırması ile incelenmiştir. Örnek olay araştırmasında temel amaç belirli bir durumdaki olguya ilişkin "ne", "nasıl" ve "niçin" sorularına cevap aramak ve süreci anlamaktır (Yin, 1999). Araştırma amacına uygun olacak şekilde Kasım ve Aralık, 2019 tarihinde yaklaşık 3 aydır faaliyet gösteren robotik uygulama ve akıllı masa uygulamasının sunulduğu yapay zekâ teknoloji örneklerinin yer aldığı bir restoranda gerçekleşmiştir. Söz konusu restoranın seçilmesinin nedeni, Türkiye'de pek fazla olmaması sebebiyle, tüketicileri araştırma amacına uygun şekilde gözlemeye olanak veren yapıya sahip olmasıdır. Araştırma süresince tüketiciler, restoranın en yoğun olduğu saatlerde gözlemlenmeye çalışılmıştır. Gözlemlemeler iki kez hafta içi, iki kez hafta sonu olacak şekilde aynı gün ve saatlerde olmasına özen gösterilerek toplamda 4 defa tekrarlanmıştır. Bilgileri doğrulamak amacıyla aynı anda ve aynı yerde iki gözlemci bulunmuştur. Ayrıca restoran yöneticisinin bu araştırmaya olumlu yaklaşması çalışmanın sağlıklı bir şekilde sürdürülmesi açısından önemlidir.

\section{BULGULAR}

İstanbul ilinde yer alan restoran, metrobüs, üniversite, alışveriş merkezine yakınlığ 1 ve yer aldığ rezidans bünyesinde bulunan şirketler açısından farklı popülasyonlara hitap edebilecek avantjlı bir bölgede yer almaktadır. Restoranda 3 robot, 14 akıllı masa bulunup, toplam 56 kişilik müşteri kapasitesine sahiptir. Restoran içerisinde ürünlerin hazırlık aşamalarının yapıldığı bir ana mutfak, pişirme ve servis aşamasının yapıldığı bir açık mutfak olmak üzere iki adet mutfak bulunmaktadır. Restoranda çalışan personel sayısı yoğunluğa göre farklılık göstermektedir. 
Hafta içi 12:00-13:00 saatleri arasında toplamda 4 personel ve 1 robot, hafta sonu 16:00-17:00 saatleri arasında ise 7 personel ve 3 robotun hizmet sunduğu gözlemlenmiştir.

Restoranda yer alan masalar, yapay zeka teknolojinin kullanıldığı akıllı masalardır. Menünün entegre edildiği bu masalarda menü kalemleri; pizza, burger, additions, salata, soğuk içecekler, sıcak içecekler, tatlılar ve kahvaltı şeklindedir. Menü içeriği incelendiğinde; 15 çeşit burger seçeneği, 10 çeşit pizza seçeneği, 3 çeşit salata seçeneği, 3 çeşit atıştırmalıklar, 1 çeşit tatlı, soğuk ve sıcak içecek çeşitleri, tek kişilik kahvaltı tabağı ve serpme kahvaltı şeklinde akıllı masaların ekranlarında yer almaktadır. Akıllı masa dışında oluşturulan menü kartı olduğu saptanmıştır. Bu menü kartında yiyecek içecek çeşitlerinin daha fazla olduğu gözlemlenmiştir. Tüketicinin dilediği ürünü dokunmatik ekranda seçmesi ve tabağına yerleştirmesi üzerine kurulmuş olan akıllı masa sistemlerinde tüketici tarafından oluşturulan sipariş, henüz entegrasyon işlemi tamamlanmadığından personel tarafından onaylanmaktadır. Sipariş aşamasında entegrasyon işleminin henüz tamamlanmamış olduğu bir seçenekte online ödeme butonudur. Tüketiciye dilediği ürünü dokunmatik ekranda seçmesini sağlayan bu sistem ayrıca ürün seçimi sonrasında internet tarayıcısı üzerinden film izleme, müzik dinleme, sosyal medya kullanımı, resim yapma, oyun oynama gibi pek çok seçenek sunmaktadır.

Restoranda servis hizmetini gerçekleştirme amacıyla geliştirilen toplamda üç adet robot yer almaktadır. Robotun kol kısmında çıkarılabilir iki kattan oluşan tepsi bulunmaktadır. Siparişin hazırlanması sonrasında garson tarafından robotun tepsi bölümüne yerleştirilen ürünler, müşterinin masasına robotlar tarafından iletilmektedir. Masalara ilerlemesi için zemin üzerinde tek şerit halinde bulunan sinyalleri takip eden robotlar, masaya ulaştığında beklemekte ve müşterinin ürünü tepsiden alması sonucunda gidebilmesi için, müşteriden kolundaki sensöre dokunmasını istemektedir. Restoran kurulumu sırasında zeminde yapılan hata sıvı ürünleri taşırken dökme problemini doğurmuş ve robotların içecek servisleri yapmasına engel olmaktadır. İçecek servisi garson tarafından yapılmaktadır.

Restoran farklı popülasyon durumlarının tespit edilmesi için hafta içi ve hafta sonu olmak üzere, yönetici tarafından alınan bilgi doğrultısunda yoğun saatler belirlenerek 2 hafta art arda hafta içi perşembe günleri 12:00-13:00 saatleri arasında, hafta sonları cumartesi günleri 16:00-17:00 saatleri arasında gözlemlenmiştir. Tüketiciler yaş gruplarına göre ayrı ayrı incelendiğinde; ilk hafta perşembe günü belirtilen saatler arasında 4 masada, 11 birey kadın, 4 birey erkek olmak üzere toplam 15 müşteri yer alırken bu masaların üç tanesinde genç öğrenciler, bir tanesinde ise yetişkin bireyler yer almaktaydı. İkinci hafta perşembe günü ise, 3 masada 9 birey kadın, 3 birey erkek olmak üzere toplamda 12 müşteri bulunurken, bu masaların bir tanesinde yetişkin bireyler, iki tanesinde ise genç öğrenciler yer almaktaydı. İlk hafta sonu cumartesi günü belirtilen saatler arasında 7 masada toplamda 23 müşteri bulunmaktaydı. Bu müşteriler arasındaki dağılıma bakıldığında; 7 çocuk, 11 kadın birey , 5 erkek birey olduğu gözlemlenmiştir. Genellikle aile yapısının gözlemlendiği müşteriler arasında yanlızca 4 birey (2 masa) bu yapıya sahil değildi. İkinci hafta sonu cumartesi günü ise, 6 masada toplamda 20 müşteri bulunmaktaydı. Bu müşteriler arasındaki dağılım ise; 6 çocuk, 9 kadın birey, 5 erkek birey şeklindedir. Yanlızca 2 masada ( 5 birey ) genç arkadaş grupları gözlemlenirken, masaların çoğunluğunda çocuklu aileler yer almaktaydi.

Müşterilerin restoranda yer alan teknolojik yeniliklere karşı tutumlarına bakıldığında; genel olarak müşterilerin, masa hakkında açılama yapmaya ve yol göstermeye gelen garson sonrasında akıllı masalardan yemek seçiminde zorlandığı, siparişi tamamlamak ve ürün içeriği hakkında bilgi almak için garsonu çağırdı gözlemlenmiştir. Arkadaşlarıyla birlikte gelen genç bireylerin sipariş sonrası çok kısa bir süre akıllı masada yer alan uygulamalara göz attığı ve sonrasında bu masalarda yer alan uygulamaları kullanmadı gözlemlenmiştir. Yetişkin ve çocuğu olan bireylerin, çocukları için burada yer alan uygulamaları kullandığı tespit edilmiştir. 
Ekranlardan son kullanılan uygulamalara bakıldığında büyük bir çoğunluğunun çocuklara yönelik videolardan oluşturduğu, ayrıca müzik, video izleme gibi uygulamalarının kullanımı ile restoranda çok fazla gürültü oluştuğu gözlemlenmiştir. Yemek servisini bekleme aşamasında bir zaman geçirme aracı olarak kullanılan bu masalara, servis sırasında ekran koruyucu özellikte petler koyulmaktadır. Ekran koruyucu olarak tabağın masa ekranı ile temasını engelleyen delikli yapıdaki bu ürün, ekranda yer alan uygulamayı izleme açısını daraltmakta ve ekran kullanımına da engel olmaktadır. Yemek servisinden sonra akıllı masaların hiç kullanılmadığı gözlemlenmiş, asıl algının robotlar üzerinde olduğu belirlenmiştir.

Restoranda tüm yaş grubunun robotlara olan ilgisinin fazla olduğu görülmüştür. Mutfak personelinin hazırladığı ürünü alan garsonun, ürünü robotun kolunda, ön kısmında yer alan tepsiye yerleştirmesi ve komut vermesi ile robot masaya doğru yönelmektedir. Masaya gelen robot tam olarak yaklaşamamaktadır. Bu durumda robotun tepsisinde olan siparişi, müşterinin alması gerekmektedir. Müşterinin ise bu sırada servisi robottan beklediği ve kısa bir süre duraksadığı, garson bilgilendirmesi sonrası siparişini aldığı gözlemlenmiştir. Her masanın robotlar ile siparişi geldiği sırada fotoğraf çektirdiği ve sosyal medya üzerinden bu fotoğrafları paylaştığı belirlenmiştir. Çocuklarına farklı deneyim yaşatma ve bir yandan da beslenmelerini sağlama amaciyla restorana getiren ailelerinde, bu teknolojiye merak duyduğu gözlemlenmiştir. Sipariş olmadığında da mutfak önünden ilerlemeye başlayan robotlar, kendisine belirlenen sinyal çizgisi üzerinde masaların yanlarından geçerek, tekrar başlangıç noktasına gelmektedir. Farklı yaş grupların tüm çocukların ilgi odağı olan robotlar, çocuklar restorandan ayrılana kadar ilgi konusu olmaktadır. Dokunmak, ses çıkarmasını sağlamak, oyun oynamak gibi amaçlarla çocuklar tarafından çalışmasına engel olunan robotlar çoğu zaman ilerlemesi gereken sinyallerin yer aldığı şeritten çıkmakta ve durmakta olduğu saptanmıştır. Çocukların robotlarla oyun oynama isteği, dokunma isteği gibi durumlarda ailelerin herhangi bir ikazda bulunmadığı ve çocukların restorandan ayrılana kadar robotların etrafında yer alarak, robotla oynama isteği, tepsi bölümüne bırakılan kişisel eşyalar ile servise engel olduğu gözlemlenmiştir.

\section{SONUÇ}

Dünyada yiyecek içecek sektörü ile ilgili pek çok alanda, yapay zekâya olan talep her geçen gün daha da belirginleşmekte ve artmaktadır. Yapay zekâ uygulamaları ve teknoloji kullanımı, yiyecek içecek sektöründe farklı bir boyut kazandırarak hızlı bir şekilde gelişmeye devam etmekte ve pek çok yiyecek içecek işletmesinde yerini almaktadır. Örneğin Güney Afrika'da ki “OppiKoppi" müzik festivalinde 150'den fazla misafire drone aracılığ 1 ile soğuk bira dağıtımı yapılmıştır (Daily News, 2013). Bu uygulamaların büyük değişikliklere sebep olacağ1 öngörülmektedir. Stephen Hawking' in "Güçlü bir yapay zekânın yükselişi insanlığın başına gelen en iyi ya da en köyü şey olabilir. Hangisi olacağın bilmiyoruz" sözleriyle belirttiği gibi bu değişimlerin nasıl sonuçlanacağı henüz bilinmemektedir.

Tüketicilere verilecek olan hizmet, insanın bu teknoloji düzeyinde teknolojiyi nasıl kullandığı, bu teknolojinin odağında hangi yaş gruplarının olduğu gibi konuları tespit etmek bu çalışmanın amacını oluşturmuştur. Gözlem tekniği ile elde edilen bulgular gözlemciler tarafından kayıt edilip analiz edilerek sunulmuştur. Yapılan gözlemler sonucunda restoranın genel özellikleri, menü içeriği, teknolojik uygulamalar, tüketici profili ve bu tüketicilerin teknolojiyi kullanım durumu ve uygulama sonucu ortaya çıkan durumlar aktarılmıştır. Bu bulgulardan yola çıkarak restoran ve tüketici hakkında yorum yapabilmek mümkündür. Restoran bulunduğu konum gereği farklı popülasyonlarda yer alan tüketicilerin kolay erişim sağlayabileceği bir mevkide yer almaktadır. Yaklaşık üç ay önce hizmete başlayan işletmede hala devam etmekte olan yapım, onarım düzenleme işlemleri vardır ve bu düzenlemeler teknik aksamalara yol açarak restoran 
izlenimini olumsuz etkilemektedir. Menü içeriği, oluşturulan menü kartı ve akıllı masada yer alan seçeneklerle örtüşmemektedir ve akıllı masa teknolojisi gereği tüketicinin kendi menüsünü seçip onaylaması gerekirken onaylama işlemi garson tarafından yapılmaktadır. Tüm bu bilgiler doğrultusunda, akıllı masaların entegrasyon işleminin henüz tamamlanmamıştır. Tüketicilere her ne kadar teknoloji sunulsa da, tüketicilerin alışmış olduğu geleneksel yöntemlere başvurma ve onay alma durumu ile hala insana olan güvencini, bağlılığını ortaya koymaktadır. Restoran tüketicine profiline bakıldığında, hafta içi öğrenciler ve restoran yakınında bulunan işyeri çalışanları bu restoranın tüketici grubunu oluştururken, hafta sonu bu durum çocuklu aileler olarak farklılık göstermektedir. Bu tüketici profilinden yola çıkarak; hafta içi ürün satma ve tüketicinin beslenme gereksinimini karşılama durumunda olan restoran, hafta sonu ürün yanında tüketiciye ürün içeriği, restoran ortamı ve farklı deneyim yaşamayı pazarlamaktadır. Robotların insanlarla etkileşiminde, tüketici profilini tanımanın ve profile uygun olacak şekilde robotların uyarlanmasının önemini vurgulayan bir çalışmada; Çinli, Koreli ve Alman toplam 108 katılımcı ile çalışmıştır. Çinli ve Koreli katılımcıların robotlarla daha fazla etkileşim içinde olduğu ve güvendiği, Alman katılımcıların ise endişeli olduğu ve olumsuz etki yarattığı soncuna varılmıştır (Li vd., 2010:180).

Günlük hayatımızın çoğu kısmında teknoloji ile içe içe olsak dahi, ilk defa karşılaşılan teknolojide her zaman bir insan tarafından anlatılma ve desteklenme gereği duyulmaktadır. Bu durumda mevcut gözlemler sonucunda şu noktaya varılmaktadır; gelişmekte olan, artan teknoloji her ne kadar insan gücüne olan ihtiyacı ve işsizliği azaltacağını öngörse de şu anda aktif olarak kullanılan bu teknoloji uygulamalarında insan gücünü göz ardı etmemektedir. Singapur'da robotik uygulamaların kullanıldığı beş restoranın yöneticileri ile yapılan bir çalışmada, yöneticiler robotik uygulamaların, insansı davranışların birçoğunu yerine getiremediği için sadece iş yükünü azalttığı ancak insan faktörünün yerine geçemeyeceğini ifade etmişlerdir (Kervenoael vd., 2019). Genç popülasyonlar, akıllı telefonlarda yer alan internet tarayıcısı ve sosyal medya uygularını gün içerisinde aktif bir şekilde kullanırken bu restoranda aynı imkânları sunan akıllı masalarda durum aynı olmamıştır. Genç bireylerin bireyselleşmesi, özel alanı olarak algıladığı sosyal medya hesaplarını toplu ortamda kullanmak istememesi gibi sebepler bu durumu açıklayabilmektedir. 2016-2017 tarihleri arasında Rus genç yetişkinlerin otellerde robotlara karşı tutumlarının araştıııldığı bir çalışmada, hizmet robotlarına karşı olumlu tutum sergilendiği saptanmıştır (Ivanov vd., 2018:4).

Robot insan etkileşimi konusunda yapılan birçok çalışma, robotiğin çocuklar üzerindeki etkisine odaklanmaktadır (Tung ve Law, 2017). Genel olarak çocuklara hitap eden robotların, güncelleme ve geliştirmeler ile işletmede yer alma amacını daha başarılı bir şekilde yerine getirmesi sağlanmalıdır. Çocukların bir oyun alanı kurgusu olarak algıladı̆̆ı ve eğlenme oyun odaklı olduğu bu restoranda, kişisel eşyaların tepsilere bırakılması ve robotla oynama gibi eylemlerin, gıda hijyenini etkileyebileceğini düşündürmüştür.

Bizleri bekleyen yakın gelecek içerisinde yiyecek içecek işletmelerinde oluşacak değişimler, bilim, mühendislik ve teknoloji sayesinde gerçekleşecektir. Yapay zekâ uygulamaları, robot teknolojilerinin kullanımı yiyecek içecek sektöründe olduğu gibi pek çok sektöre yayılarak, yaşamımızın bir parçası haline dönüşeceği aşikârdır. Örneğin günümüzde turizm alanında kullanımına bakıldığında çağı yakalamaya çalışan ve teknolojik yenilikleri takip eden oteller tarafından, restoranların yiyecek ve içecek kalitesini, güvenliğini geliştirmek, hizmete yardımcı olmak gibi sebeplerle tercih edildiği görülmektedir. Bu oteller arasında yer alan Starwood Aloft Oteli, misafirlerine konfor sağlamak, yardımcı olabilmek adına robot Boltr'u geliştirmiştir. Royal Caribbean Otelinde ise, bar bölümünde robotlardan oluşan bir garson timi oluşturmuştur (Tung ve Law, 2017). Bu bilgiler doğrultusunda sektörün hizmet odaklılık ve insan boyutu ele alındığında teknolojinin getirmiş olduğu yenilikerin yiyecek içecek anlayışı ve kavramı üzerinde 
kalıcı sonuçlar oluşturacağını iddia etmek mümkündür. Müşteri memnuniyetini arttıran ve farklı deneyimler sunan bu uygulamaların yiyecek içecek işletmelerinde karlılığı arttırma konusunda olumlu etkileri olacağı söylenebilir. Türkiye 'de henüz çok yeni olan bu teknolojik uygulamaların kısa bir zaman içerisinde hızlıca gelişerek sektörde yer alacağı öngörülmektedir. Bu çalışma Türkiye'de yiyecek içecek alanında henüz çok yeni olan teknolojik uygulamaların kullanımını tespit etmek açısından ve literatürde buna benzer bir çalışma olmamasından dolayı önem kazanmaktadır. Çalışma yapılacak sonraki çalışmalar için yol gösterici olabilir ve daha net tespitler yapabilmek adına farklı yiyecek içecek restoranlarında teknoloji kullanım durumu ölçülebilir. Gün geçtikçe yaşamımızın bir parçası haline gelecek olan teknoloji uygulamaları, yakından takip edilerek yiyecek içecek sektöründe tüketiciler için yeni ve farklı hizmetler geliştirerek tüketici beklentilerini karşılamalı ve Dünya' da ki benzer gelişmeler takip edilerek sektörün gelişmesi sağlanmalıdır.

\section{KAYNAKÇA}

Diaz, J. (2019). Domino's Now Using AI and Cameras to Make 'Perfect' Pizzas. [Online] https://www.tomsguide.com/us/dominos-pizza-dom-ai-pizza-checker,news-30182.html> [Erişim Tarihi: 28.11.2019].

Eriksen, K. (2019). Benefits of Artificial Intelligence in the Restaurant Industry [Online] https://www.deputy.com/blog/benefits-of-artificial-intelligence-in-the-restaurant-industry> [Erişim Tarihi: 28.11.2019].

Ertürk, F. E., ve Yayan, G. (2012). Bilim ve Sanatı Birleştiren İki Usta. Batman Üniversitesi Yaşam Bilimleri Dergisi, 1(1), 453-464.

Fourtané, S. (2018). Discover the Virtual Reality Cocktail Bar: The Place For The Drinks of the Future. [Online] https://interestingengineering.com/discover-the-virtual-reality-cocktail-bar-theplace-for-the-drinks-of-the-future> [Erişim Tarihi: 28.11.2019]

Garver, K. (2018). 6 Examples of Artificial Intelligence in the Food Industry. [Online] https://foodindustryexecutive.com/2018/04/6-examples-of-artificial-intelligence-in-the-foodindustry> [Erişim Tarihi: 27.11.2019]

Geijer, T. (2019). Food tech: technology in the food industry Robot arm offers the food industry. [Online] https://www.ingwb.com/media/2917160/food-tech-report_april-2019> [Erişim Tarihi: 28.11.2019]

Gomez, A. H., Hu, G., Wang, J., and Pereira, A. G. (2006). Evaluation of tomato maturity by electronic nose. Computers and Electronics in Agriculture, 54(1), 44-52.

https://www.gastrograph.com/index.html [Erişim Tarihi: 26.11.2019]

https://www.inamorestaurants.london [Erişim Tarihi: 27.11.2019]

https://itrestaurant.net/cafetable [ Erişim Tarihi: 24.11.2019]

https://www.marketwatch.com/press-release/symphony-retailai-named-a-recipient-of-supplydemand-chain-executives-green-supply-chain-awards-2018-12-12 [Erişim Tarihi: 28.11.2019]

https://www.mordorintelligence.com/industry-reports/artificial-intelligence-in-food-and beverages-market [Erişim Tarihi: 01.12.2019]

https://www.nottingham.ac.uk/news/pressreleases/2016/september/new-ai-driven-cleaningsystem-could-save-food-manufacturers-100m-a-year.aspx [Erişim Tarihi: 27.11.2019] 
https://www.spyce.com/ [Erişim Tarihi: 24.11.2019]

https://www.tomra.com/en/sorting/food/food-technology [Erişim Tarihi: 27.11.2019]

Ivanov, S., Webster, C., and Garenko, A. (2018). Young Russian adults' attitudes towards the potential use of robots in hotels. Technology in Society, 55, 24-32.

Kayıkçı, M. Y., ve Bozkurt, A. K. (2018). Dijital Çağda Z Ve Alpha Kuşağı, Yapay Zeka Uygulamaları Ve Turizme Yansımaları. Sosyal Bilimler Metinleri, 2018(1), 54-64.

Kervenoael, R. D., Hasan, R., Schwob, A., and Goh, E. (2019). Leveraging Human-Robot İnteraction İn Hospitality Services: Incorporating. Tourism Management, 78, 1-15.

Kızıl, Ü., Genç, L., ve Saçan, M. (2011). Elektronik Burun Sistemlerinin Tasarım İlkeleri. U. Ü. Ziraat Fakültesi Dergisi, 25(1), 109-118.

Korel, F., ve Balaban, M. Ö. (2003). Uses of Electronic Nose in the Food Industry. Gida Teknolojisi Dergisi, 28(5), 505-511.

Kozak, M. (2018). Bilimsel Araştırma: Tasarım, Yazım ve Yayım Teknikleri. (4. Basım), Ankara: Detay Yayıncilik.

Li, D., Rau, P. P., and Li, Y. (2010). A Cross-cultural Study: Effect of Robot Appearance and Task. International Journal of Social Robotics, 2(2), 175-186.

Margetis, G., Grammenos, D., Zabulis, X., and Stephanidis, C. (2013). iEat: An Interactive Table for Restaurant Customers' Experience Enhancement. International Conference, 23-23 July 2013,Las Vegas.

Murkett, R. (2017). How Artificial Intelligence Can Help F\&B Supply Chain Management. [Online] https://www.foodonline.com/doc/how-artificial-intelligence-can-help-f-b-supply-chainmanagement-0001> [Erişim Tarihi: 27.11.2019].

News, D. (2013). Drone delivers beers - not bombs - at South Africa music festival. [Online] https://www.nydailynews.com/> [Erişim Tarihi: 17.12.2019].

Sennaar, K. (2019). Examples of AI in Restaurants and Food Services. [Online] https://emerj.com/ai-sector-overviews/ai-in-restaurants-food-services> [Erişim Tarihi: 25.11.2019].

Sharma, S. (2019). How Artificial Intelligence is Revolutionizing Food Processing Business?. [Online] https://towardsdatascience.com/how-artificial-intelligence-is-revolutionizing-foodprocessing-business-d2a6440c0360> [Erişim Tarihi: 24.11.2019].

Sofu, A., Demir, N., ve Ekinci, F. Y. (2007). Gıda Bilimi ve Teknoloji Alanında Yapay Zeka Uygulamaları. Gida, 32(2), 93-99.

Topdemir, H. G. (2011). Geç İskenderiye Döneminde Bilim: İskenderiyeli Heron. Bilim ve Teknik Dergisi(529), 90-92.

Tung, V. W., and Law, R. (2017). The Potential For Tourism and Hospitality Experience Research in Human-Robot Interactions. International Journal of Contemporary Hospitality Management, 29(10), 2498-2513.

Türken, T., ve Pala, T. (2016). Vişne Suyunun Antioksidan Aktivite Değerinin Yanıt Yüzey Metodu İle. El-Cezerî Fen ve Mühendislik Dergisi, 3(2), 238-247. 
Utermohlen, K. (2019). 4 Applications of Artificial Intelligence in the Food Industry. [Online] https://heartbeat.fritz.ai/4-applications-of-artificial-intelligence-ai-in-the-food-industrye742d7c02948> [Erişim Tarihi: 25.11.2019].

Walker, W. L. (2018). AI in Food Dish Preparation - Mouth Watering Food Prepared By Robots. [Online] https://crowbarprotein.com/ai-in-food-dish-preparation> [Erişim Tarihi: 28.11.2019].

Walker, W. L. (2018). AI in Restaurants - Changing How Restaurants Function Forever. [Online] https://crowbarprotein.com/ai-in-restaurants> [Erişim Tarihi: 28.11.2019].

Yıldırım, A., ve Şimsek, H. (2016). Nitel Araştırma Yöntemleri (10. Basım), Ankara: Seçkin Yayıncilik.

Yıldız, M., ve Yıldırım, B. F. (2018). Yapay Zeka ve Robotik Sistemlerin Kütüphanecilik Mesleğine Olan Etkileri. Türk Kütüphaneciliği, 32(1), 26-32.

Yin, R. K. (1999). Enhancing the quality of case studies in health services research. Health Services Research, 34(2), 1209-1224.

Yülek, M. (2018). 11. Kalkınma Planı ve Türkiye'nin robotları. [Online] https://www.dunya.com/kose-yazisi/11-kalkinma-plani-ve-turkiyenin-robotlari/401624\#> [Erişim Tarihi: 01.12.2019]. 